\title{
Risk of Shallot Supply Chain from Production Center in Cirebon to Consumption Center in Jakarta, Indonesia
}

\author{
Susanawati Susanawati ${ }^{1, *}$ \\ ${ }^{I}$ Department of Agribusiness Universitas Muhammadiyah Yogyakarta, Indonesia \\ "Corresponding author.Email: susanawati@umy.ac.id
}

\begin{abstract} risk.

Keywords: supply chain, risk, AHP, shallot.

\section{INTRODUCTION}

The largest shallot producing area in West Java Province is Cirebon Regency, followed by Majalengka, Bandung, and Garut Regencies. The shallot planting season in Cirebon Regency occurs three times in one year, namely April December for farmers close to water sources and April August for those far from water sources. This condition shows that in certain months there is abundant production and other months of little production, giving rise to problems in the amount of supply in the market including Pasar Induk Kramatjati Jakarta (PIKJ).
\end{abstract}

The majority of shallot distribution from Cirebon production centers to Jakarta consumption centers passes through the actors in Brebes, so that many actors involved can raise risk-sharing problems. Therefore, research needs to be aimed at finding out the network in the shallot supply chain from the Cirebon production center to the consumption center in Jakarta and analyzing the risk in the chain. Respondents used were experts consisting of government representatives, academic representatives, and practitioners, namely the supply chain actors themselves. Description analysis in the form of a flow chart to describe the network in the shallot supply chain. The AHP (Analytical Hierarchy Process) model is used to analyze the risk of shallot supply chains. The results showed that the network in the shallot supply chain from Cirebon to Jakarta was formed by eight actors namely farmers, Cirebon panders, entrepreneurs in Brebes, Brebes senders, PIKJ croupiers, PIKJ centheng, retailers, and consumers. The results of AHP analysis showed that partnership risk is the most important risk in the shallot supply chain from Cirebon Regency to Jakarta, followed by quality risk and price

The majority of shallot distribution from Cirebon Regency to Jakarta passes through entrepreneurs and shippers in Brebes Regency [1]. A large number of actors involved makes the performance of the chain not good because each actor has their own level of importance, thus raising a number of issues of risk-sharing among actors. Based on these conditions, the purpose of this study is to describe the network in the shallot supply chain from Cirebon Regency to Jakarta and analyze the risks in the supply chain.

Supply chain risk is damage that occurs due to an event in a company, in the supply chain or its environment [2]. Risk evaluation based on expert opinion is referred to as a qualitative risk evaluation model and deterministic and statistical evaluation methods are called quantitative risk evaluation models [3]. Several previous studies on the evaluation of supply chain risk have been carried out by several experts, such as who used AHP to select off-shore locations in supply chain networks with internal and external risk-based who used linear programming optimization to maximize profits with risk considerations. In addition, the use a dynamic simulation system in the supply chain risk management model [4-8]. This study uses qualitative methods with the AHP (Analytical Hierarchy Process) model because the analysis is qualitative. The results of this study can be used as information to improve supply chain performance, especially in minimizing risks that occur along the chain.

\section{METHODS}

The research location was determined intentionally in Cirebon Regency because it was one of the centers of shallot production in Java and even Indonesia after Brebes Regency in Central Java and Nganjuk District in East Java. There are 14 sub-districts in Cirebon Regency which produce shallots. Gebang Sub-district is the region that has the largest shallot production in Cirebon Regency, which is 120,100 quintals (Cirebon Regency in 2010). 
Based on the selected sub-district, namely Gebang Subdistrict, then one village was taken which had the highest number of shallot production, namely Gebang Village. The farmers' sampling technique is done intentionally. From the number of shallot farmers population as many as 150 people who are members of Sari Tani farmer groups, taken as many as 30 people randomly. This number is based on the opinion of Nasution (1996), which states that the number of respondents is considered representative and meets the minimum requirements if there are $10 \%$ of the population members. Sampling of panders, entrepreneurs, and senders is done in combination between snowball sampling and information from PPL at the research location. The number of panders in Gebang Village is 10 people and in the Gebang District level there are 20 people. The number of panders samples used in this study was 5 people. The number of large-scale entrepreneurs in Bulakamba District, Brebes Regency who received shallots from Cirebon brokers was approximately 20 people and in this study 5 people were used. Sender of red onion was taken as many as 5 people from a population of 25 people.

This study also uses expert respondents consisting of government, academics, and supply chain actors from Cirebon Regency to Jakarta. Expert respondents were used for the purpose of identifying and assessing the risk of each shallot supply chain actor. The number of expert respondents used in this study were academic experts (1 person), government / bureaucrats 1 person, and practitioners consisting of supply chain actors from Cirebon Regency to Jakarta each of them 1 person. Expert respondents were selected purposively with the following criteria:

a. Has a reputation for expertise and has demonstrated credibility as an experienced expert in the supply chain of agricultural products.

b. Know the general conditions of cultivation, postharvest, and marketing of shallots.

c. Know the knowledge of the sources of risks and risks that may be faced by actors in the supply chain of agricultural products, especially shallots.

The risk analysis of shallot supply chain uses AHP model through expert choice software version 9. stated that AHP has many advantages in explaining the decision-making process, because it can be graphically illustrated. In addition, AHP also tested the consistency of the assessment. The working principle of the AHP model according to are as follows [9]:

\section{a. Defining the problem}

The problem is defined by analyzing or understanding the problem to be solved, namely the risk of shallot supply chains. The next process is to identify and select elements that will be included in the hierarchical system components, such as goals, objectives, actors, and alternatives.

\section{b. Make a hierarchical structure}

Hierarchy is an abstraction of the structure of a system that studies interactions between components and their impact on the system. The hierarchical structure is based on the types of decisions that will be taken based on viewpoints from peak level to the level where it is possible to intervene to solve the problem. The hierarchical structure can be obtained by studying previous research literature and or through expert opinion. The hierarchical structure in this study consists of 4 levels including goals at the first level, goals at the second level, actors / criteria at the third level, and alternatives at the fourth level. Goal is identification the risk of shallot supply chain players. The objectives of identifying supply chain risks are three, namely the smooth flow of goods, the flow of money, and the flow of information, supply chain efficiency, and the balance of benefits between supply chain actors. The actor or criterion is a chain of shallot supply actors from Cirebon Regency to Jakarta. The alternatives in the form of the types of risks faced by shallot supply chain actors are 12 types of risks, namely production, environmental, quality, price, supply, transportation, partnership, information, market, storage, technology and government policies. Determination of these types of risks is based on literature review and interviews with chain actors.

\section{c. Evaluating hierarchy level}

The process of evaluating each level of the hierarchy is done to determine the elements that most influence the overall goal. The step in this stage is to make an assessment of the relative importance of two elements at a certain level with the level above. The results of the evaluation are presented in the form of a matrix called the nxn-sized pairing matrix. To evaluate the comparison of the level of importance of an element to other elements can be referred to the opinion through a scale of 1 to below [11].

Determination of Weight or Priority of Elements Penentuan Bobot atau Prioritas Elemen

Determining the weight or priority of each level of the hierarchy is carried out in pairs (pairwise comparisons). The pairwise comparison process starts at the top of the hierarchy (goal) that will be used to make the first comparison. Relations between elements from each level of the hierarchy are determined by comparing the elements in pairs. The relationship describes the influence of relative elements at the hierarchy level on each element at a higher level. Elements at a higher level function as a criterion and are called properties. The result of this differentiation process is a priority vector or relative importance of elements to each trait. Pairwise comparisons are repeated again for all elements in each level. The final step is to weight each vector with its priority. 


\section{a. Logical Consistency}

Consistency is done to obtain valid results in the real world. AHP measures consistency in all evaluations through a comparison of consistency ratios. Value consistency ratio must be less than $10 \%$. If more than $10 \%$, the evaluation needs to be improved. The consistency ratio is calculated by the formula:

$\mathrm{CI}=\frac{\lambda_{\max }-\mathrm{n}}{\mathrm{n}-1}$ and $\mathrm{CR}=\frac{\mathrm{CI}}{\mathrm{RI}}$

Information:

$\mathrm{CI}=$ Consistency Index

$\mathrm{CR}=$ Consistency Ratio

$\mathrm{RI}=$ Random Index

$\mathrm{n}=$ Matrix Size

To find out the Random Index value can use the rules contained in Table 1.

Table 1. Random Index Value (RI)

\begin{tabular}{|l|l|l|l|}
\hline Matrix Size & RI & Matrix Size & RI \\
\hline 1 & 0 & 9 & 1,45 \\
\hline 2 & 0 & 10 & 1,49 \\
\hline 3 & 0,58 & 11 & 1,51 \\
\hline 4 & 0,90 & 12 & 1,48 \\
\hline 5 & 1,12 & 13 & 1,56 \\
\hline 6 & 1,24 & 14 & 1,57 \\
\hline 7 & 1,32 & 15 & 1,59 \\
\hline 8 & 1,41 & & \\
\hline
\end{tabular}

\section{RESULTS AND DISCUSSION}

\section{Network in the Shallot Supply Chain}

The network in the shallot supply chain from Cirebon Regency to Jakarta was formed by eight actors, namely farmers, Cirebon panders, entrepreneur in Brebes, Brebes senders, PIKJ croupier, PIKJ centhengs, retailers, and the last consumers in Jakarta. The full network chart can be seen in Figure 1. In the figure, it can be seen that to get to consumers in Jakarta, shallot from Cirebon passes the entrepreneurs and sender in Brebes Regency. The role of panders in Cirebon becomes an intermediary between farmers and entrepreneurs in Brebes.

\section{Shallot Supply Chain Risk Analysis Hierarchical Structure}

The hierarchical structure in the shallot supply chain from Cirebon Regency to Jakarta consists of four levels, namely goals at the first level, goals at the second level, actors / criteria at the third level, and alternatives at the fourth level. The complete picture of the hierarchical structure is presented in Figure 2. The actors in the hierarchy consist of actors on the shallot chain from Cirebon Regency to Jakarta consisting of eight actors such as those found in the network above. The alternatives are 12 types of risks, namely $\mathrm{R} 1$ = production risk; $\mathrm{R} 2$ = environmental risk; R3 = quality risk; $\mathrm{R} 4=$ price risk; $\mathrm{R} 5=$ supply risk; $\mathrm{R} 6=$ transportation risk; $\mathrm{R} 7=$ partnership risk; $\mathrm{R} 8=$ information risk $\mathrm{R} 9=$ market risk; $\mathrm{R} 10=$ storage risk; $\mathrm{R} 11$ $=$ technology risk; R12 = risk of government policy.

\section{Goal' Identifikasi risiko pelaku rantai pasok bawang merah}

kelancaran alian produksi| Efisiensi Rantai Pasok | Keseimbangan keuntungan antar pelaku rantai

\section{Petani Calo Pengusahal lapak di Cirebon Pengirim Bandar di PIK] Centheng di PIK] Pedagang pengecer Konsumen}

$$
\begin{array}{lllllllllllllllll}
\hline \text { R1 } & \text { R2 } & \text { R3 } & \text { R4 } & \text { R5 } & \text { R6 } & \text { R7 } & \text { R8 } & \text { R9 } & \text { R10 } & \text { R11 } & \text { R12 } \\
\hline
\end{array}
$$

Figure 1. Shallot Supply Chain Hierarchy Structure from Cirebon Regency to Jakarta

\section{Comparison of Inter-Criteria Pairings}

According to experts from the government for the criteria of supply chain efficiency and the balance of profits between actors is equally important or has the same priority, then the next priority is the smooth flow of goods, the flow of money, and the flow of information. The evaluation is different from academic experts, where the three criteria used are considered equally important. Government experts have such an assessment because according to him the smooth flow of goods, the flow of money, and the flow of information in the field is not a problem (Figure 2).

According to farmers and panders in Cirebon Regency, the smooth flow of goods, the flow of money, and the flow of information occupy the top priority, then the next priority is the criteria for supply chain efficiency and profit balance between actors. This condition is due to farmers being only in the realm of production, so that the smooth flow of goods, the flow of money, and the flow of information are prioritized criteria. For panders the smooth flow of products, the flow of money, and the flow of information is a priority because it relates to its role as an intermediary between farmers and prospective buyers.

The criteria for the balance of profits between chain actors are a top priority according to the evaluation of entrepreneur in Brebes. While the second and third priorities according to croupier evaluation are the smooth flow of goods, money flow, and information flow and supply chain efficiency. Entrepreneurs in Brebes evaluate that the smooth flow of goods, the flow of money, and the flow of information and supply chain efficiency have the same priority after the balance of benefits between actors. The entrepreneur in Brebes realizes that in the shallot supply chain there has not been a balance of benefits between the perpetrators, so that is the priority [12].

The sending experts in Brebes, the croupier in PIKJ, and centheng at the PIKJ have the same evaluation where the three criteria are the smooth flow of goods, the flow of 
money, the flow of information; supply chain efficiency; and the balance of benefits between chain actors has the same priority to pay attention to. This condition shows that the three criteria are equally important. According to retailers in Jakarta, the criteria for supply chain efficiency and the balance of profits between chain actors are both top priorities, then the flow of goods, money flows, and information flows is followed. Consumers in Jakarta evaluate that the smooth flow of goods, the flow of money, and the flow of information is a top priority, then the next priority is supply chain efficiency and profit balance between actors with the same priority level. For consumers who are important, shallots are always on the market, so they do not see other criteria [13].

Joint evaluation among actors that shows supply chain efficiency is a top priority that must be considered, then the second and third priorities are the criteria for the balance of profits between chain actors and the smooth flow of goods, money flows, and information flows. This condition shows that all actors want efficiency in the supply chain as a top priority that must be considered. According to them, if efficiency has been achieved in the supply chain of shallots, then naturally there has been a smooth flow of goods, the flow of money, and the flow of information and the balance of benefits between actors.

Model Name: RANTAI CIREBON
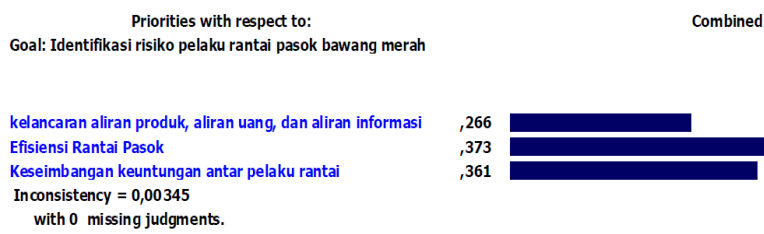

Figure 2. Comparison of Inter-Criteria Pairings

\section{Comparison of Pairs between Sub Criteria}

The actors who are interested in the sub-criteria for the smooth flow of goods, the flow of money, and the flow of information are farmers, then followed by brokers, senders in Brebes, lapak entrepreneurs in Brebes, retailers, consumers, croupiers in PIKJ, and the last centheng at PIKJ. This situation occurs because farmers as suppliers of shallots in the chain, so that the smooth flow of goods, the flow of money, and the flow of information are determined by the conditions of farmers' shallot production (Figure 3).

Entrepreneurs in Brebes became interested actors in supply chain efficiency sub-criteria, then were only followed by senders in Brebes, PIKJ croupier, farmers, retailers, centheng at PIKJ, pander, and last consumers. Entrepreneurs in Brebes are large-scale collectors at the district level, so that supply chain efficiency can be initiated from these actors. This condition is also supported by its vital role in the shallot trade from Cirebon Regency to Jakarta.

The actors who are most interested in the sub-criteria for profit balance between chain actors are farmers, then only the senders at Brebes, entrepreneurs in Brebes, PIKJ croupier, retailers, centheng at PIKJ, pander, and the last consumers. So far, the farmers who experience the greatest risk are related to shallot production and do not have a bargaining position. In addition, new farmers get profits after approximately two months and even then have to bear the cost of production with loan capital, so that it is appropriate for farmers to most want a balance of profits.

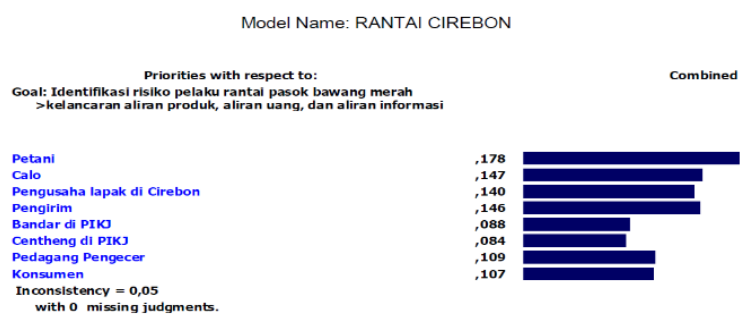

Figure 3. Comparison of Pairs between Sub Criteria

\section{Result of Supply Chain Risk Synthesis}

According to academic experts the five biggest risks that need attention in the shallot supply chain from Cirebon Regency to Jakarta are partnership risk, price risk, quality risk, market risk, and supply risk. Whereas according to experts from the government are partnership risk, price risk, quality risk, policy risk, and market risk. In the opinion of the two experts, the difference lies in supply risk and policy risk. Supply risk is considered important by academic experts because shallot is produced seasonally so continuity of supply becomes a problem that must be addressed (Figure 4). Government experts consider policy risk to be included in five types of risk because they feel that the policy was made by him and sometimes in the field technically the policy is sometimes not on target [14]. Farmers consider that the five biggest risks are production risk, price risk, environmental risk, quality risk, and transportation risk. Production risk is the first risk for farmers because these farmers carry out the production process and who face these risks. Price and quality also cause farmers to be in a risky condition, because the quality of shallots produced during harvest determines the selling price at the farmer's level.

Pander evaluates that the five biggest types of risk in the shallot supply chain are partnership risk, quality risk, price risk, market risk, and supply risk. The risk of partnership is in the first place because so far panders have worked with entrepreneurs in Brebes in the sale of shallots and in fact there are often delays in the case of payments not even being paid, so panders are often scolded by farmers [15]. 
The five biggest risks according to the evaluation of entrepreneurs in Brebes are quality risk, partnership risk, market risk, storage risk, and environmental risk. Shallot for the purpose of the PIKJ is wet with leaves that are still green and in the form of rogolan. This condition causes variations in the quality or quality of the shallots [16].

Sender at Brebes considers that partnership risk, quality risk, market risk, information risk, and production risk are the five biggest risks that must be considered. The partnership is a risk factor because the sender buys shallots from entrepreneurs who often play with prices. Market conditions also cause the sender to be at risk due to uncertainty in the amount of supply or supply to the PIKJ. For example, a dealer orders in a certain amount and price, but because when the onion arrives at PIKJ it turns out the amount of supply is abundant, there is a decrease in prices. That condition caused many senders to switch to the Cibitung or Outside Java market [17].

Croupier and Centheng at PIKJ give an evaluation that the five biggest types of risk are partnership risk, price risk, quality risk, market risk, and supply risk. Centheng is the only actor who can buy shallots directly to the city and has been provided by the port as much as requested, so as if a partnership between the two has been established. These conditions sometimes pose a risk because the croupier feels powerful or stronger than the centheng, so there is a price play. Quality causes risk because thecroupier sells the shallot that he buys to centheng in conditions as it is from the sender, so that there are variations in the size of each package [18]. Centheng also bought red onion from centheng inside packed in a red plastic bag (waring), so there was also variation in size.

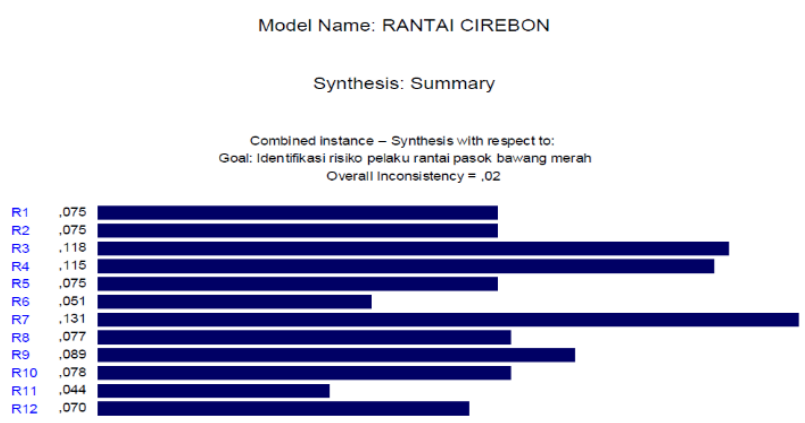

Figure 4. Result of Supply Chain Risk Synthesis

The five biggest types of risk according to retailers in Jakarta are quality risk, partnership risk, price risk, market risk, and production risk. The retailer buys shallots to centheng in PIKJ in two forms, skin peel and with skin. Usually the peeled shallot quality is unclear in terms of size and color, even though the price is more expensive. According to a joint evaluation of shallot supply chain actors, the five biggest risks that must be considered in the shallot supply chain from Cirebon Regency to Jakarta are partnership risk, quality risk, price risk, market risk, and supply risk. The partnership has become the biggest risk because so far the trade in shallots has not yet established a partnership even though there are already supporting facilities such as cooperatives, special markets for shallots, the Indonesian Shallot Association (ABMI).

\section{CONCLUSION}

The network in the shallot supply chain from Cirebon Regency to Jakarta was formed by eight actors, namely farmers, Pander in Cirebon, Entrepreneurs in Brebes, Brebes senders, PIKJ croupier, PIKJ centheng, retailers, and consumers. The results of pairwise comparisons in the AHP model show that supply chain efficiency is the most important thing for risk analysis, then followed by a balance of profits between actors, and finally the smooth flow of products, flow of money, and flow of information. The results of risk analysis with the AHP model show that there are three biggest risks that need to be considered in the shallot supply chain from Cirebon Regency to Jakarta, namely partnership risk, quality risk, and price risk [19]. These results have implications for the need to improve the partnership system that has been carried out between panders in Cirebon Regency, entrepreneurs in Brebes.

\section{REFERENCES}

[1] Susanawati, S., Jamhari, J., Masyhuri, M. and Darwanto, D.H., 2016. Integrasi pasar bawang merah di Kabupaten Nganjuk (pendekatan kointegrasi Engle-Granger). AGRARIS: Journal of Agribusiness and Rural Development Research, 1(1), pp.43-51.

[2] Kersten, W, Hohrath, P, Boger, M. 2007. An Empirical Approach To Supply Chain Risk Management: Development of A Strategic Framework. Proceeding POMS 2007 Conference.

[3] Klimov R.A, Merkuryev, Y.A. 2006. Simulation Model for Supply Chain Reliability Evaluation. Technology and Economic Development of Economy 14 (3) : 300-311.

[4] Wu, D., Olson, D.L. 2008. Supply Chain Risk, Simulation, and Vendor Selection. International Journal Production Economics doi : 10. 1016/j.ijpe.2008.02.2013.

[5] Schoenherr, k.J, rao, T.V.M., Harrison, T.P. 2008. Assesing Supply Chain Risk with Analytic Herarchy Process. Providing decision support for the offshoring decision by a US manufacturing company. Journal of Purchasing and Supply Management, doi : $10.1016 /$ j.pursup. 2008.01.008. 
[6] Nagurney A, Cruz JM, Dong J. 2005. Global Supply Chain Networks and Risk Management : A Multi-Agent Framework, publish in MultiagentBased Supply Chain Management, B. Chaib-draa and J.P. Muller, Editors, Springer, berlin, Germany : 103-134.

[7] Li, J, and Hong, S.J., 2007. Towards a New Model of Supply Chain Risk Management : the Cross-Functional Process Mapping Approach. International Journal Electronic Customer Relationship Management. 1(1) : 91-107.

[8] Lee, T.Y.S, 2008. Supply Chain Risk Management. International Journal Information and Decision Sciences. 1(1) : 98-114.

[9] Marimin, Djatna.T, Suharjito, Hidayat. S, Utama, D.N, Astuti.R, and Martini.S. 2013. Fuzzy Decision Making Techniques and Analysis in Supply Chain Management. IPB Press. Kampus IPB Taman Kencana Bogor.

[10] Hakimi, R. 2007. Strategies for Increasing the Competitiveness of the Nata de Coco Industry in the City of Bogor with a Fuzzy Approach. Thesis. Postgraduate School. Agricultural Industrial Technology Program. IPB. Bogor.

[11] Saaty, T.L. 1989. Decision Making, Scalling, and Number Crunching. Decision Science. 20(2) : 404-409.

[12] Chapman, P., Christopher, M., Juttner, U., Peck, H., Wilding, R. 2002. Identifying and Managing
Supply Chain Vulnerability. Logistic and Transport Focus : Journal Institute of Logistics and Transport 4 : 59-64.

[13] Juttner, U., Peck, H., Christopher ,M. 2003. Supply Chain Risk Management : outlining an agenda for future research. International Journal Logistic : Research and Applications. 6(4) : 197 201.

[14] Singarimbun,M. and S. Effendi, 1989. Survey Research Methods. Institute for Research and Education and Assessment of Social Economics (LP3ES). Jakarta.

[15] Subyantoro, A. and F.X. Suwarto, 2007. Methods and Techniques of Social Research. Andi Yogyakarta. Yogyakarta.

[16] Suharjito. 2011. Modelling of Intelligent Chain Management Supply Decision Support Systems for Corn/Production Commodities. Postgraduate School Dissertation. IPB. Bogor.

[17] Thompson, H.C. and Kelly, C.N. 1987. Vegetable Crops. Fifth edition. McGraw Hills Book Coompany, New York, Toronto London.

[18] Widodo, E. and Mukhtar, 2000. Construction in Descriptive Research Direction. Avyrous. Yogyakarta.

[19] Xiaohui, W., Xciaobing,Z., Shiji, S., Chenf, W. 2006. Study on Risk Analysisi of Supply Chain Enterprises. Journal Systems Engineering and Electronics. 17(4) : 781-787. 